\title{
Micromole per Minute
}

National Cancer Institute

\section{Source}

National Cancer Institute. Micromole per Minute. NCI Thesaurus. Code C85708.

Micromoles per minute. 